University of Nebraska - Lincoln

DigitalCommons@University of Nebraska - Lincoln

Restoration of spermatogenesis after transplantation of c-Kit positive testicular cells in the fowl

\author{
Pavel Trefil \\ BIOPHARM, trefil@bri.cz \\ Murray R. Bakst \\ United States Department of Agriculture \\ Haifen Yan \\ HIAVS \\ Jiří Hejnar \\ Academy of Sciences of the Czech Republic \\ Jiří Kalina \\ BIOPHARM
}

See next page for additional authors

Follow this and additional works at: https://digitalcommons.unl.edu/usdaarsfacpub

Part of the Agricultural Science Commons

Trefil, Pavel; Bakst, Murray R.; Yan, Haifen; Hejnar, Jiř́; Kalina, Jiří; and Mucksová, Jitka, "Restoration of spermatogenesis after transplantation of c-Kit positive testicular cells in the fowl" (2010). Publications from USDA-ARS / UNL Faculty. 675.

https://digitalcommons.unl.edu/usdaarsfacpub/675

This Article is brought to you for free and open access by the U.S. Department of Agriculture: Agricultural Research Service, Lincoln, Nebraska at DigitalCommons@University of Nebraska - Lincoln. It has been accepted for inclusion in Publications from USDA-ARS / UNL Faculty by an authorized administrator of DigitalCommons@University of Nebraska - Lincoln. 


\section{Authors}

Pavel Trefil, Murray R. Bakst, Haifen Yan, Jiří Hejnar, Jiří Kalina, and Jitka Mucksová 


\title{
Restoration of spermatogenesis after transplantation of c-Kit positive testicular cells in the fowl
}

\author{
Pavel Trefil ${ }^{\mathrm{a}, *}$, Murray R. Bakst ${ }^{\mathrm{d}}$, Haifeng Yan ${ }^{\mathrm{b}}$, Jiří Hejnar ${ }^{\mathrm{c}}$, Jiří Kalina ${ }^{\mathrm{a}}$, \\ Jitka Mucksováa \\ a BIOPHARM, Research Institute of Biopharmacy and Veterinary Drugs, a.s. 25449 Jílové u Prahy, Czech Republic \\ ${ }^{\mathrm{b}}$ HIAVS, Hunan Institute of Animal and Veterinary Science, Quantang, Changsha 410131, Hunan, China \\ ${ }^{\mathrm{c}}$ Institute of Molecular Genetics, Academy of Sciences of the Czech Republic, Flemingovo náměstí 2, CZ-16683 Prague 6, Czech Republic \\ d Animal Biosciences \& Biotechnology Laboratory, Agricultural Research Service, US Department of Agriculture, Beltsville, MD 20705, USA
}

Received 20 November 2009; received in revised form 8 July 2010; accepted 8 July 2010

\begin{abstract}
Transplantation of male germ line cells into sterilized recipients has been used in mammals for conventional breeding as well as for transgenesis. We have previously adapted this approach for the domestic chicken and we present now an improvement of the germ cell transplantation technique by using an enriched subpopulation of c-Kit-positive spermatogonia as donor cells. Dispersed c-Kit positive testicular cells from 16 to 17 week-old pubertal donors were transplanted by injection directly into the testes of recipient males sterilized by repeated gamma irradiation. We describe the repopulation of the recipient's testes with c-Kit positive donor testicular cells, which resulted in the production of functional heterologous spermatozoa.

Using manual semen collection, the first sperm production in the recipient males was observed about nine weeks after the transplantation. The full reproduction cycle was accomplished by artificial insemination of hens and hatching of chickens.

(C) 2010 Elsevier Inc. All rights reserved.
\end{abstract}

Keywords: Chicken; Spermatogenesis; Transplantation; Testicular cells; c-Kit receptor

\section{Introduction}

Transplantation of male germ line cells from a donor animal to the testes of an infertile or sterilized recipient was first developed in rodents [1]. This technique has now been used in a number of animal species, including domestic mammals [2], fish [3], and chicken [4,5]. Donor germ cells repopulate the spermiogenic epithelium in recipient's testis and produce fertile donor-derived sperm, such that the recipient male can distribute the genetic material of the germ cell donor. Transplantation of

\footnotetext{
* Corresponding author. Tel.: +420-241950383; fax: +420241950503.

E-mail address: trefil@bri.cz (P. Trefil).
}

male germ cells is a uniquely valuable approach for the study of spermatogenesis, preservation of animal genetic resources and transgenesis [1].

Spermatogenesis is characterized by sequential steps of cell proliferation and differentiation resulting in the continuous production of spermatozoa [6]. The principal role in this system is played by the spermatogonial stem cells, which have the unique potential for both self-renewal and gradual differentiation of daughter cells towards spermatozoa [7-9]. In mammals, particularly in mouse and rat, there is relatively extensive knowledge of the molecular and biochemical characteristics of spermatogonial stem cells. The knowledge of proper markers in this cell population made possible their isolation and increased the efficiency of male germ line transplantation 
[10]. In contrast, our understanding of spermatogenesis in chicken is much poorer and transcriptomic, proteomic as well as cytochemical characterizations of testicular cells are urgently needed for the progress of male germ line transplantation. Morphological and histochemical identification of stem spermatogonial populations in post-hatch individuals has been successfully performed only in fixed preparations of testicular tissues from quail and turkey [11-13] but remains to be established in fresh preparations. DNA content can be used as another marker for flow-cytometry sorting of various subpopulations of testicular cells in chicken [14].

In the absence of proper marker proteins specific for chicken spermatogonial stem cells, we can get some insight from the analogy with mouse. Here, the stem cell marker gene Stra 8 has been identified among genes expressed at an early stage of spermatogenesis [15]. Additional observations by the same authors indicated the genes Dazl, c-Kit, Hsp70-2 and Crem $\tau$ as markers expressed prior to the first meiotic division. Particularly, Dazl and c-Kit genes are expressed only in the side population (SP) and tetraploid cells whereas transcription of Hsp70-2 and Crem $\tau$ genes occurs at or after the spermatocyte stage [16]. Barocca et al [10] described that c-Kit-positive spermatogonial progenitors represent the majority of SP in adult mice and, although committed to differentiate, retain at least low potential to recover spermatogenesis after transplantation into germ cell-depleted recipient testes. On the other hand these authors showed the highest regenerative potential for SP fraction of undifferentiated spermatogonial cells expressing $\alpha-6$ integrin and with none or low expression of c-Kit. In the present study, we assessed the suitability of c-Kit for the selection of donor testicular cells able to colonize sterilized recipient testes in our original and well established system of male germ line transplantation in chicken $[4,17]$.

\section{Materials and methods}

\subsection{Experimental animals and irradiation treatment}

A total of seven pubertal, 16-17 week-old inbred Barred Leghorn (BL; genotype ii, Ee, B/b) fowl males were used as donors. The seven recipient males were 26 week-old (adult) White Leghorns (WL; genotype II). Two males having the same genetic origin as recipients were kept as positive controls while three other WL males of the same origin were subjected to the same treatment as the recipient males but kept as negative controls (described hereafter). All birds used in these experiments were obtained from the Experimental An- imal Farm of the Institute of Molecular Genetics, Prague, Czech Republic. All experiments were performed in accordance with Czech legal requirements for animal handling and welfare.

All Barred Leghorn hens (BL; genotype ii, ee, B/-) and males were kept in individual pens $\left(4200 \mathrm{~cm}^{2}\right)$ under standard husbandry conditions with photoperiod 12L:12D. Feed and water were provided ad libitum. Incubations were performed in a forced air incubator (BIOS MIDI, Czech Republic) adjusted for fowl egg incubation conditions.

Theratron T1000 radiation treatment unit (Theratronics International Ltd., Kanata, Ontario, Canada) was used to irradiate WL testes according to the previously described protocol [17]. Briefly, each male was subjected to five irradiations ( $8 \mathrm{~Gy}$ each) repeated at 3-4 day intervals.

\subsection{Chicken germ line cell transplantation model}

Phenotypic identification of one-day-old chicks issued from ova fertilized by heterologous sperm was made possible by using feather markers [4]. c-Kitpositive testicular cells from BL donors possessed barred phenotype due to homozygous recessive (ii) alleles at the I (white) locus while the WL sterilized males were homozygous dominant (II) at the I (white) locus. The dominant I allele of this locus originates the white phenotype of WL fowl males through the epistatic inhibition of the $\mathrm{E}$ allele encoding eumelanin. The specific e allele ('recessive black') in the used chicken lines confers a similar phenotype as the E allele. The dominant allele bar (B) is incompletely dominant in BL hens and is localized on the $\mathrm{Z}$ chromosome. It is phenotypically expressed as striping with broad stripes in cockerels (BB) or narrow stripes in cockerels $(\mathrm{Bb})$ and narrow stripes in hens $(\mathrm{B})$, or black color in hens (b-). Hence, the phenotype in the F1 progeny after AI of the BL hens with semen of the recipient WL males was used to evaluate the success of the transplantation of c-Kit-positive testicular cells. A black or barred phenotype in the F1 progeny indicated successful transplantation and restoration of normal spermatogenesis from donor (BL) germ cells, while the presence of white chicks in the F1 progeny indicated incomplete sterilization and persistence of WL germ cells.

\subsection{Preparation and selection of c-Kit-positive donor germ cells}

All donor males were sacrificed by decapitation and their testes quickly removed and washed in phosphate buffered saline (PBS). Testicular cells were isolated 
from the cockerel testes by performing a two-step enzymatic digestion of testicular tissues in order to remove interstitial cells. Briefly, the tunica albuginea was removed and the seminiferous tubules dissociated by enzymatic digestion in $100 \mathrm{U} / \mathrm{ml}$ Type I collagenase (BIOCHROM AG, Germany) for 50 minutes at $34{ }^{\circ} \mathrm{C}$ in $\mathrm{PBS}, \mathrm{pH} 7.2$, supplemented with 1,2 mM MgSO4, 1,3 mM $\mathrm{CaCl}_{2}, 6,6 \mathrm{mM}$ sodium pyruvate, and glutamine. The resulting suspension was filtered to remove cell clumps. After washing in PBS, the cell pellet was resuspended in PBS and the dispersed cells were washed twice in PBS for 5 minutes each wash. Mouse anti-chicken c-Kit conjugated with biotin diluted 1:40 was applied and after 30 min at $4{ }^{\circ} \mathrm{C}$, all c-Kit-positive cells were selected using magnetic activated cell sorting (MACS) according to Dynal (Norway) instructions. The c-Kit-positive cells obtained in this way were subsequently used in germ line transplantation experiments.

\subsection{Flow cytometry analysis and description of c-Kit positive testicular cells in cell mixture}

Single cell suspensions of testes tissue were labeled with monoclonal antibody anti-c-Kit conjugated with phycoerythrin (Southern Biotech, Birmingham, $\mathrm{AB}$ ). The identification of c-Kit-positive testicular cells was performed on the basis of their DNA content using testicular cell suspensions stained with $5 \mu \mathrm{M} \mathrm{H} 33342$ diluted in PBS for $90 \mathrm{~min}$ at $37{ }^{\circ} \mathrm{C}$. The analyses of cell cycle in these cells were performed from cell suspensions stained for 30 min with $10 \mu \mathrm{M} \mathrm{H} 33342$ diluted in PBS at room temperature and $5 \mu \mathrm{g} / \mathrm{ml}$ propidium iodide (PI) was used as a counter stain to exclude non-viable cells (red fluorescence of their nuclei). Flow cytometry analyses were performed with a FACSVantage SE flow cytometer (Becton Dickinson, Franklin Lakes, $\mathrm{NJ})$ equipped with the two-stream argon-helium laser (Coherent Enterprise EE, Orsay, France). The various categories of cells stained by $\mathrm{H} 33342$ were excited by a UV laser adjusted to $50 \mathrm{mV}$ using a combination of $485 \mathrm{~nm}$ long-pass and $505 \mathrm{~nm}$ shortpass filters in front of the first detector. Cell populations stained with PI were detected with a 682 $\mathrm{nm} / 22 \mathrm{~nm}$ bandpass filter in front of the second detector. Fluorescence intensity was measured as a linear scale. Some cell types display shift of fluorescence into red light after staining with H33342. Dead cells were not visible because they were outside the frame of the diagram. Control of the elimination of dead cells was made possible by using PI staining (excitation wavelength: $488 \mathrm{~nm}$ ).

\subsection{Transplantation of c-Kit positive cells}

Approximately $300 \mu \mathrm{L}$ of the dispersed c-Kit positive testicular cells with cell densities varying from $10^{5}$ to $10^{6}$ cells $/ \mathrm{mL}$ were administered into each of the testis of the seven anaesthetized recipient WL males. Three additional WL males subjected to the same sterilization treatment were kept as negative controls. Recipient males were anesthetized with an intramuscular injection of a mixed preparation of $15 \mathrm{mg} / \mathrm{kg}$ ketamine (Narkamon, Spofa, Czech Republic) and $4 \mathrm{mg} / \mathrm{kg}$ xylazine (Rometar, Spofa, Czech Republic). c-Kit-positive cells were then applied through the tunica albuginea at four to five different locations randomly distributed among each testis.

\subsection{Assessment of the sperm output}

Ejaculates from transplanted and control males were collected once a week for 13 weeks using the conventional abdominal massage technique [18]. To determine the number of sperm per ejaculate, sperm concentration was estimated with a prescaled centrifuge [19] and the volume with a scale (nearest $\mathrm{mg}$ ). Weekly semen output (WSO, [20]) per male was estimated by addition of the number of ejaculated spermatozoa per week.

\subsection{Artificial insemination (AI) with semen from transplanted males}

Outbred BL hens were AI with semen collected from WL recipient males (2) in which semen production resumed after transplantation. Six hens (three per cockerel) were inseminated twice a week with individual ejaculates from transplanted males producing spermatozoa and their eggs (32 eggs per hen) in 4 batches were incubated under standard conditions. Intra-vaginal inseminations were performed with $2 \times 10^{5}$ spermatozoa per hen diluted in $100 \mu \mathrm{L}$ BPSE [21] in duration of seven weeks. The percentage of hatched eggs was determined from the number of eggs incubated divided by the total number of eggs incubated.

\subsection{Statistical analysis}

Test of equality of the linear regression line between two males that ejaculated heterologous populations of sperm was done by Chow test and compared by $\mathrm{F}$ distribution. (Statistica 7.1, StatSoft). 


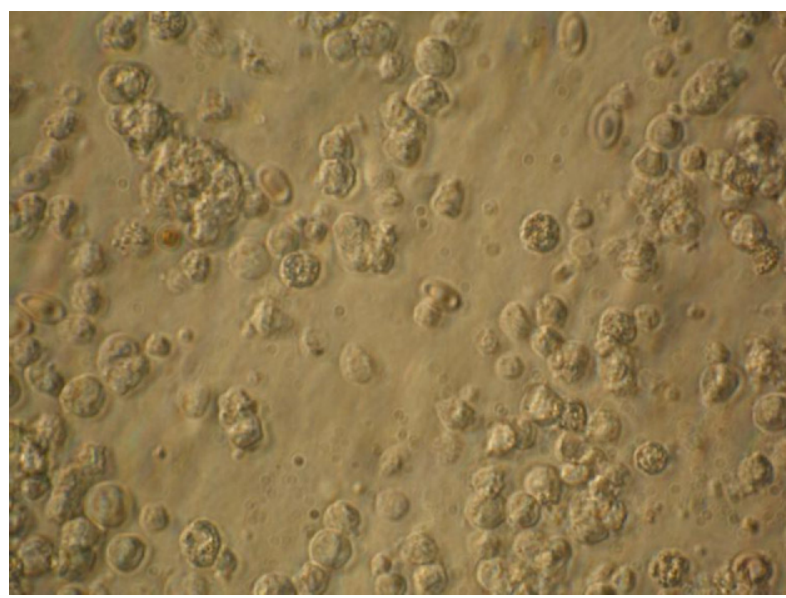

Fig. 1. Clumps of c-Kit-positive cells selected from testicular cells of a 16-17 week-old cockerel after magnetic cell sorting (original magnification $\times 400)$.

\section{Results}

\subsection{Sterilization of recipient testes and their re-population with labeled donor dispersed testicular cells}

Within one month after the sterilization of recipient males no semen was expressed by manual semen collection. At that point the recipient males were ready for transplantation of donor c-Kit positive testicular cells (Fig. 1).

\subsection{DNA content of c-Kit positive cells}

The flow cytometric analyses showed that the used isolation procedure resulted in $2.16 \% \mathrm{c}$-Kit positive

A

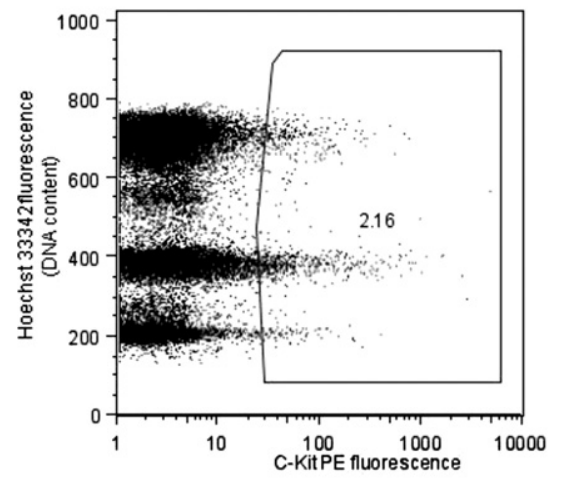

cells in the isolated testicular cells from 16 to 17 weekold cockerels (Fig. 2A). In separate analyses, based on Hoechst 33342 staining of nuclei, the percentages of the c-Kit positive donor testicular cells with haploid, diploid, and tetraploid DNA content was 7.8\%, 51.8\% and $28.3 \%$, respectively (Fig. 2B).

\subsection{Restoration of spermatogenesis in recipient testes}

Five weeks after transplantation, higher numbers of spermatozoa were observed in the ejaculates of two WL males out of the seven WL recipients. Sperm output from recipient males started on week 5 after transplantation and then gradually increased up to week 13, reaching an average of $350 \times 10^{6}$ sperm/wk (see Fig. $3 \mathrm{~A}, \mathrm{~B})$, i.e. 15 times less compared to average cockerel semen week output. Males A and B differed in the number of ejaculated spermatozoa produced after transplantation. The three age-matched sterilized but non-transplanted WL males (negative control) failed to produce semen after attempts at manual semen collection.

\subsection{Hatched chicks}

Two out of seven recipients transplanted with dispersed testicular cells from pubertal donors successfully produced progeny expressing donor cell phenotypes (Table 1). Six hens were inseminated with semen collected from these two recipients in course of 7 weeks and egg lay resulted in totally 195 eggs hatched in four batches.
B

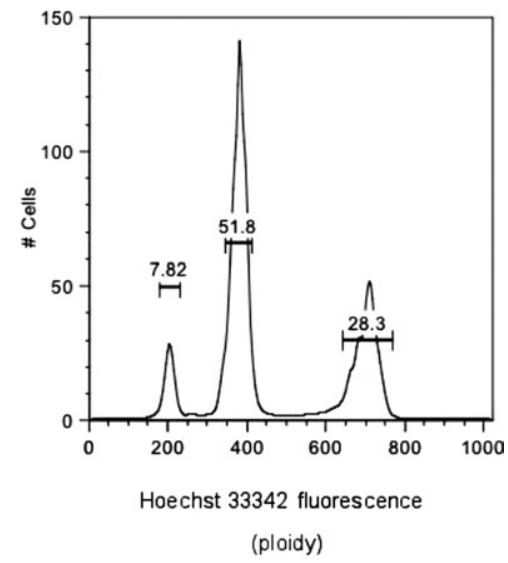

Fig. 2. Flow cytometric analysis of c-Kit positive pubertal cockerel testicular cells stained with Hoechst 33342 and anti-c-Kit conjugated with phycoerythrin (c-Kit PE) (A) and percentages of the c-Kit positive dispersed donor testicular cells with haploid, diploid, and tetraploid DNA content (B). 

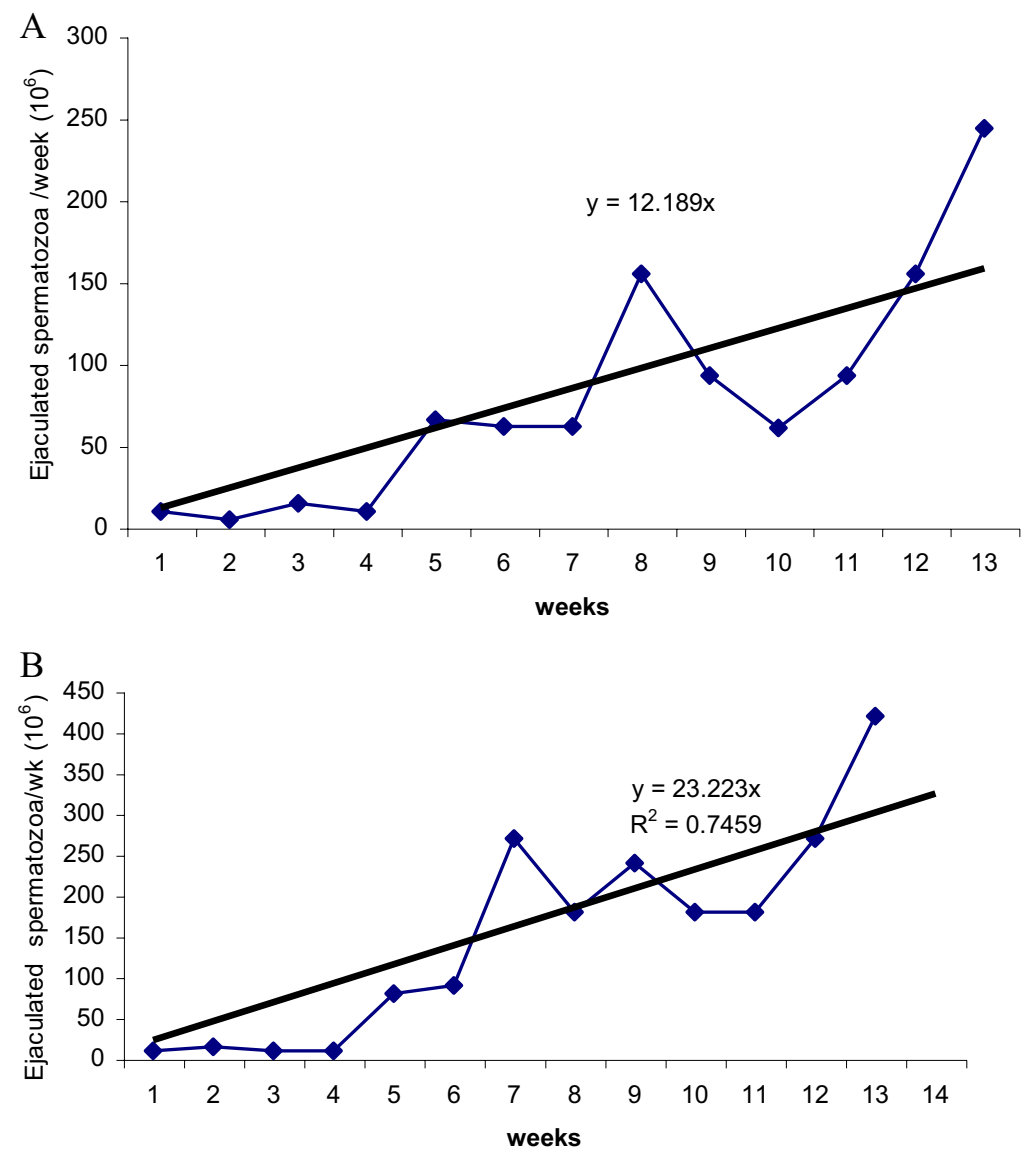

Fig. 3. Time course of the weekly sperm output in two (A and B) WL recipient chicken males transplanted with dispersed c-Kit positive testicular cells from BL donors. Zero represents first day after transplantation.

Of the 110 hatched eggs from hens inseminated with semen from these two males, 26 chicks (24\%) expressed the following phenotypes: barred cockerels (ii, Ee, B/b or Ee, B/B or ee, $\mathrm{B} / \mathrm{B}$ or ee, $\mathrm{B} / \mathrm{b}$ genotype), black hens (ii, Ee, b- or ee, b-), or barred hens (Ee, B- or ee, B-). The remaining chicks (76\%) from these two males were white chickens (Ii) apparently suggesting that donor cells apparently did not fully outnumber the background of White genotype stem cells, which still remained intact after incomplete sterilization (Table 2).

\section{Table 1}

Frequency of sperm recovery and percentage of males with achieved fertility in fowl males primarily transplanted with dispersed testicular cells from pubertal or adult donors.

Age of BL donors (weeks) No. (\%) of WL recipients producing progeny carrying donor genes/total number of transplanted cockerels

$16-17$ $2 / 7(29)^{x}$

\section{Discussion}

In the present study, we have shown that dispersed c-Kit positive testicular cells from 16 to 17 week-old cockerels have the capacity of successful re-colonization of the seminiferous epithelium, resumption of spermatogenesis, and the production of viable and functional spermatozoa after transplantation into sterilized recipient testes. When inseminated into hens, sperm from two of the seven recipients produced chicks expressing the donor's haplotype, thus reproducing previous work in the mouse [22,23] and chicken [4]. It was apparent that c-Kit positive testicular cells from 17 week old cockerels were suitable as donor cells for transfer to recipient males. What was not so apparent was that the percentage of c-Kit positive cells from the younger males $(2.16 \%)$ was nearly twice as high as that recovered from the adult males $(1.27 \%)$ in our previous results. We were able to identify c-Kit-positive testicular cells in all main parts of the cell cycle, i.e. we 
Table 2

Hatchability of eggs after the insemination with semen of WL recipients producing progeny carrying donor genes.

\begin{tabular}{cccccc}
\hline $\begin{array}{c}\text { Age of BL donors } \\
\text { (weeks) }\end{array}$ & $\begin{array}{c}\text { No. of incubated } \\
\text { eggs }\end{array}$ & $\begin{array}{c}\text { No. of fertile } \\
\text { eggs }(\%)\end{array}$ & $\begin{array}{c}\text { No. of hatched eggs } \\
\text { from fertile eggs }(\%)\end{array}$ & $\begin{array}{c}\text { No. of barred hatched } \\
\text { chickens }(\%)\end{array}$ & $\begin{array}{c}\text { No. of white hatched } \\
\text { chickens }(\%)\end{array}$ \\
\hline $16-17$ & 195 & $146(74.8)$ & $110(75.3)$ & $26(24)$ & $84(76)$ \\
\hline
\end{tabular}

described the highest amount $(51.8 \%)$ in diploid cell subpopulation, $28.3 \%$ in tetraploid cell subpopulation and $7.8 \%$ in haploid cell subpopulation. In comparison with testicular cells without the selection for c-Kit [14], we found a slight increase in the fraction of diploid cells, whereas the fraction of haploid cells was reduced to $7.8 \%$. Presence of haploid cells can be due to random admixture of spermatids into the subpopulation of c-kitselected cells.

There is the possibility of nonspecific binding of anti c-Kit antibody on the surface of some haploid cells. However, these cells were not included in the process of renewal spermatogenesis.

$\mathrm{F} 1$ progeny resulting from the $\mathrm{AI}$ of $\mathrm{BL}$ hens with semen collected from transplanted WL males revealed that only $24 \%$ of the chicks possessed barred or black phenotypes and the remaining $76 \%$ of the hatch were white chick (Ii). This means that sterilization of the recipient males had apparently been incomplete although the control, non-transplantated animals did not restore spermiogenesis and the transplanted animals were negative as well at the time immediately before transplantation when examined by the control of ejaculates. Not all transplanted recipients restored spermatogenesis suggesting that the transfer process was either inefficient or the seeded donor cells failed to colonize the recipients seminiferous epithelium. The fact that five complete sterilized recipient cockerels failed to resume spermiogenesis, while two apparently incompletely sterilized cockerels resume spermiogenesis, may, if not coincidence, suggests that milder irradiation may have been more suitable for colonization of transplanted spermatogonia and that completely sterilized testes were also damaged during the process of sterilization. For the efficient repopulation of spermiogenic epithelium, however, a specific subpopulation of c-Kitpositive cells must be present in the mix of transplanted cells and this selection for c-Kit positivity could then be used for enrichment of the mixture.

We also experienced technical problems with the precise orientation of the gamma radiation on the abdominal testes during the sterilization process. This erratic irradiation probably allowed some spermatogonia in the recipient's seminiferous epithelium to survive to produce sperm concurrently with the transferred c-
Kit positive cells. This supports our previous observations [17] where we confirmed that repeated exposure of mature fowl testes to gamma irradiation resulted only in a partial elimination of germ cell populations and that seminiferous tubules exposed to such radiations kept in a pre-functional state. We also revealed for the first time in chicken that c-Kit positive testicular cells transferred into recipient testes maintain their potential to restore spermatogenesis in heterologous testes, which is similar to that previously performed in the mouse [10].

The recovery of functional heterologous spermatozoa was observed in two out of seven recipients produced semen and is a consequence of transferring donor c-Kit positive testicular cells rather than the unselected dispersed donor testes cells used previously [17]. Given that the spermatogonia stem cell is most likely a c-Kit-positive cell, we assume that a larger percentage of the donor cells transferred into the recipient testes were spermatogonia, thus also increasing chances for a successful seed of the sterilized seminiferous epithelium.

Unfortunately, there are no reliable morphological criteria or readily identifiable surface markers to differentiate the spermatogonial stem cell from the other spermatogonial subtype. Consequently, the precise number of stem spermatogonia transferred into each male recipient is not known. However, we suspect that a significant percentage of the transferred cells did not seed seminiferous tubules but were lost to the interstitial spaces. Ogawa et al [23,24] noted that the number of colonies re-colonizing seminiferous tubules was indicative of the number of stem spermatogonia transferred to the recipient in mice.

In conclusion, about $24 \%$ ( 26 chicks) of the fertilized eggs from hens inseminated with heterologous semen were fertilized with sperm derived from the donor c-Kit-positive cell population. When optimized, this approach could be an alternative to PGC manipulation and gene transfer in avian species. Furthermore, this technique can also be used as a mean to restore endangered or lost lines of birds, thus opening new approaches to preservation of genetic resources in avian species. 


\section{Acknowledgments}

This research was supported by Grant No. ME 908 AMVIS, ME 10104 CONTACT and grant No. 523/07/ 1171 awarded by the Czech Science Foundation. We would like to thank Vanda Dziedicova for her skilled technical assistance in the treatment of cockerels, Zdeněk Cimburek for FACS analyses and Věra Fialová for statistical analysis.

\section{References}

[1] Brinster RL, Zimmermann JW. Spermatogenesis following male germ cell transplantation. Proc Natl Acad Sci USA 1994; 91:11298-302.

[2] Izadyar F, Den Ouden K, Stout TA, Stout J, Coret J, Lankveld DP, Spoormakers TJ, Colenbrander B, Oldenbroek JK, Van der Ploeg KD, Woelders H, Kal HB, De Rooij DG. Autologous and homologous transplantation of bovine spermatogonial stem cells. Reproduction 2003;126:765-74.

[3] Majhi SK, Hattori RS, Yokota M, Watanabe S, Strüssmann CA. Germ cell transplantation using sexually competent fish: an approach for rapid propagation of endangered and valuable germlines. PLoS One 2009;4(7):e6132.

[4] Trefil P, Mičáková A, Mucksová J, Hejnar J, Bakst MR, Poplštein M, Kalina J, Brillard JP. Restoration of spermatogenesis and male fertility by transplantation of dispersed testicular cells in the chicken. Biol Reprod 2006;75:575-81.

[5] Kalina J, Senigl F, Micakova A, Mucksova J, Blazkova J, Yan H, Poplstein M, Hejnar J, Trefil P. Retrovirus-mediated in vitro gene transfer into chicken male germ line cells. Reproduction 2007; 134:445-53.

[6] Russell LD, Ettlin RA, Sinha Hikim AP, Clegg ED. Histological and Histopathological Evaluation of the Testis. Cache River Press; Clearwater, Florida; 1990.

[7] Huckins C. Cell cycle properties of differentiating spermatogonia in adult Sprague-Dawley rats. Cell Tissue Kinet 1971;4: 139-54.

[8] Clermont Y. Kinetics of spermatogenesis in mammals: seminiferous epithelium cycle and spermatogonial renewal. Physiol Rev 1972;52:198-236.

[9] Meistrich ML, van Beek MEAB. Spermatogonial stem cells. In: Desjardins C, Ewing LL, editors. Cell and Molecular Biology of the Testis. Oxford Univ Press: New York; 1993. p. 266-95.

[10] Barroca V, Lassale B, Coureuil M, Louis JP, Le Page F, Testart J, Allemand I, Riou I, Foucht P. Mouse differentiating sper- matogonia can generate germinal stem cells in vivo. Nat Cell Biol 2009;11:190-6.

[11] Lin M, Jones RC. Renewal and proliferation of spermatogonia during spermatogenesis in the Japanese quail Coturnix coturnix japonica. Cell Tissue Res 1992;267:591-601.

[12] Jones RC, Lin M. Spermatogenesis in birds. Oxf Rev Reprod Biol 1993;15:233-64.

[13] Bakst MR, Akuffo V, Trefil P, Brillard JP. Morphological and histochemical characterization of the seminiferous epithelial and Leydig cells of the turkey. Anim Reprod Sci 2007;97:303-13.

[14] Mucksová J, Brillard JP, Hejnar J, Poplštein M, Kalina J, Yan H, Bakst MR, Trefil P. Identification of various testicular cell populations in pubertal and adult cockerels. Anim Reprod Sci 2009;114:415-22.

[15] Ouland-Abdelghani M, Bouillet P, Decimo D, Gansmuller A, Heyberger S, Dolle P, Bronner S, Lutz Y, Chambon P. Characterization of a premeiotic germ cell-specific cytoplasmic protein encode by Stra8, a novel retinoic acid-responsive gene. J Cell Biol 1996;135:469-77.

[16] Bastos H, Lassalle B, Chicheportiche A, Riou L, Testart J, Allemand I, Fouchet P. Flow cytometric characterization of viable meiotic and postmeiotic cells by Hoechst 33342 in mouse spermatogenesis. Cytometry 2005;65A:40-9.

[17] Trefil P, Polak J, Poplstein M, Mikus M, Kotrbova A, Rozinek J. Preparation of fowl testes asrecipient organs to germ-line chimeras by means of gamma-radiation. Br Poult Sci 2003;44: 643-50.

[18] Burrows WH, Quinn JP. Collection of spermatozoa from domestic chicken and turkey. Poult Sci 1937;16:19-24.

[19] Bonitz W. Die Ermittlung des Spermazellvolumens in Ejakulaten von Hähnen mit Hilfe der Mikro-Kapillarmethod. Archiv für Geflügelzucht und Kleintierkunde 1970;19:193-201.

[20] Amann RP. Sperm production rates. In: Johnson AD, Gomes WR, Vandemark NL, editors. The testis, Vol 1. New York: Academic Press; 1970. p. 433-72.

[21] Sexton TJ, Fewlass TA. A new poultry semen extender 2. Effect of the diluent components on the fertilizing capability of chicken semen stored at $5^{\circ} \mathrm{C}$. Poult Sci 1978;57:277-84.

[22] Brinster RL. Germline stem cell transplantation and transgenesis. Science 2002;296:2174-6.

[23] Ogawa T, Dobrinski I, Avarbock MR, Brinster RL. Transplantation of male germ line stem cells restores fertility in infertile mice. Nat Med 2000;6:29-34.

[24] Ogawa T, Dobrinski R, Brinster RL. Recipient preparation is critical for spermatogonial transplantation in the rat. Tissue Cell 1999;31:461-72. 